\title{
Fatal acute Chagas disease by Trypanosoma cruzi DTU Tcl, Ecuador
}

\author{
Manuel Calvopina ${ }^{* *}$ (D), Gabriela Segovia², William Cevallos², Yosselin Vicuña², Jaime A. Costales ${ }^{3}$ and Angel Guevara ${ }^{2}$
}

\begin{abstract}
Background: Chagas disease is caused by the haemoflagellate protozoan Trypanosoma cruzi. Currently, T. cruzi recognizes seven discrete typing units (DTUs): Tcl to TcVl and Tcbat. The genetic diversity of T. cruzi is suspected to influence the clinical outcome. Acute clinical manifestations, which include myocarditis and meningoencephalitis, are sometimes fatal; occur most frequently in children and in immunocompromised individuals. Acute disease is often overlooked, leading to a poor prognosis.

Case presentation: A 38-year-old man from a subtropical area of the Andes mountains of Ecuador was hospitalized after 3 weeks of evolution with high fever, chills, an enlarged liver, spleen, and lymph nodes, as well as facial edema. ECG changes were also observed. T. cruzi was identified in blood smears, culture and amplification of DNA by PCR. Tests for anti-T. cruzi IgG and IgM and HIV were negative. Molecular typing by restriction fragment length polymorphism (PCR-RFLP) determined the parasite to DTU Tcl. In the absence of a timely anti-T. cruzi medication, the patient died.

Conclusions: This is a case of severe pathogenicity and the virulence of a DTU Tcl strain in an adult patient. The severe acute Chagas disease was probably overlooked due to limited awareness and its low incidence. Our findings suggest that T. cruzi DTU Tcl strains circulating in Ecuador are capable of causing fatal acute disease. Early diagnosis and prompt treatment is of paramount importance to avoid fatalities in acute infections.
\end{abstract}

Keywords: Trypanosoma cruzi, Tcl, DTU, Fatal acute Chagas disease, Ecuador

\section{Background}

Data from the World Health Organization indicate that 6-7 million individuals are infected by Trypanosoma cruzi, from the south of the United States to the north of Argentina and Chile, with approximately 60-70 million people at risk of infection; Chagas disease is considered a neglected tropical disease [1].

Infected individuals may present with clinical manifestations of different levels of severity. The genetic diversity of $T$. cruzi is suspected to influence the clinical outcome although no definitive associations have been unequivocally identified [2,3]. Seven genetic lineages or discrete typing units (DTUs) are currently recognized, named TcI through TcVI and Tcbat [3]. All lineages are

\footnotetext{
*Correspondence: manuelcalvopina@gmail.com;

manuel.calvopina@udla.edu.ec

${ }^{1}$ OneHealth Research Group, Carrera de Medicina, Facultad de Ciencias de la Salud, Universidad de Las Américas (UDLA), Calle Jose Queri s/n entre Av. Granados y Av. Eloy Alfaro, PO BOX 17-17-9788, Quito, Ecuador

Full list of author information is available at the end of the article
}

present throughout the Americas, although TcI predominates in northern region of South America, and occurs in both domestic and sylvatic cycles of the parasite [2]. In addition, $\mathrm{TcI}$ infections are frequently reported in the northern section of the Amazon, where patients can display severe acute clinical manifestations, including cardiomyopathy and death [2]. TcI has also been isolated from chronic chagasic cardiomyopathy and reactivation disease [4]. TcII, TcV, and TcVI are associated with chronic cases presenting megaesophagus and megacolon in the southern cone countries $[5,6]$.

The acute phase of Chagas disease is usually asymptomatic; however, when symptoms do occur, they may include high fever, malaise, enlargement of the liver, spleen, and lymph nodes; as well as subcutaneous edema (localized or generalized) [7]. ECG changes are also common [2]. Death can occur in the acute phase $(<5-10 \%$ of symptomatic cases) due to severe myocarditis, meningoencephalitis, or both [7-9] and in some cases due to acute kidney failure (AKF) [10]. In addition, fatal cases with disseminated and

(c) The Author(s). 2020 Open Access This article is distributed under the terms of the Creative Commons Attribution 4.0 International License (http://creativecommons.org/licenses/by/4.0/), which permits unrestricted use, distribution, and 
diffuse foci have been observed [5]. Severe acute Chagas disease and related deaths occur most frequently in children, the elderly and immunocompromised individuals or in those who are receiving immunosuppressive drugs or organ transplants $[4,6,7]$.

Chagas disease is endemic in Ecuador, country located in the northwest region of South America. TcI is clearly the predominant DTU, and has been the only DTU isolated from triatomines, rodents and opossums in the central Pacific coast and in southern Ecuador [4, 11]. However, a couple of reports exist in the literature suggesting the presence of genetic lineages other than TcI in Ecuador [12, 13]. $T$. cruzi infection is considered a public health problem in Ecuador, because it is endemic in the Amazon, the Pacific coast and in some subtropical areas of Andes mountains [7, 14]. The Pan-American Health Organization (PAHO) and the Ecuadorian Ministry of Public Health (MPH) estimate the general prevalence of $T$. cruzi infection to be $1.38 \%$ of the general Ecuadorian population with annual mortality of 7.7 per 1000 seropositive, meaning that there are 1300 deaths annually due to Chagas [http://chagas.zoonosis.gub. uy/Documentos/Ecuador/ Control_dela_Enfermedad_de_ Chagas_en_Ecuador_OPS_Chagas.pdf. CP 17-1106292]. However, information is scarce regarding the genetic diversity of human isolates. Herein, we report a case of Chagas disease in a 38-year-old man who died in the acute phase due to myocarditis and renal failure. The patient was infected in the western foothills of the Andes close to the central Pacific coastal region, and the parasite isolated from his blood was determined to belong to T. cruzi DTU TcI.

\section{Case presentation}

A farmer of 38-year-old man was admitted to a hospital with fever $\left(39^{\circ} \mathrm{C}\right)$, chills, malaise, anorexia, generalized pallor, hepatosplenomegaly, lymphadenopathy, weight loss, facial edema, and an ulcerous skin lesion in his left leg. The patient was born and always lived in a locality of La Maná-Cotopaxi province; a subtropical area located in the western foothills of the Andes, close to the central Pacific coastal region, some $130 \mathrm{~km}$ from the capital Quito. The patient reported neither receiving blood transfusions nor travelling within or outside Ecuador.

Since December 2014, he had a 22-day history of high fever, chills and malaise being treated with antibiotics and antipyretics in a public health center. Five days prior to hospital admission, he was diagnosed with $T$. cruzi infection via microscopic observation in peripheral blood. Due to unavailability of anti-T. cruzi drugs, he was transferred to a hospital. The patient reported of having an insect bite in his left leg approximately 10 days prior to the development of the fever. The bite became a pruritic indurated papule, which subsequently ulcerated and did not heal even with the use of an antibiotic cream. The patient was hospitalized with a diagnosis of acute Chagas disease, in order to receive treatment with benznidazole, the drug recommended by the Ecuadorian MPH [14].

At the beginning of hospitalization, microscopic examination of thick and thin smears of peripheral blood confirmed the presence of $T$. cruzi, and was negative for malaria parasites. T. cruzi was cultured in LIT medium. The parasites were spotted on FTA Classic Card (Whatman, Newton Center, MA). Blood tests showed a white blood cell count of $6.8 \times 10^{9} / \mathrm{L}$, with $44.8 \%$ neutrophils, 45.9\% lymphocytes, $7.3 \%$ monocytes, $1.2 \%$ eosinophils and $0.8 \%$ basophils. The erythrocyte sedimentation rate was $40 \mathrm{~mm} /$ hour, with a hemoglobin of $8.4 \mathrm{~g} / \mathrm{dL}$, a hematocrit of $25.4 \%$, and a platelet count of $152,000 / \mu \mathrm{L}$. VDRL, HBsAg, HBcAg, HCV, ELISA and Western blot for HIV, and the test for febrile agglutinations (Brucella spp., typhoid and paratyphoid fevers), were all negative. Serum glucose, urea and creatinine were 77, 173 and 7.7 $\mathrm{mg} / \mathrm{dL}$, respectively. Serological tests for anti-T. cruzi IgG and IgM (Chagatest ELISA recombinant, Version 3.0. Wiener-Argentina) were negative. Blood, urine and skin ulcer cultures for bacteria were negative. Paracetamol $(1 \mathrm{~g})$ was administered every $8 \mathrm{~h}$ as an anti-febrile agent.

The EKG showed left anterior fascicular hemi block, QRS $0.10 \mathrm{mms}$, marked deviation of the axis to the left (positive QRS in I and negative in AVF), small R waves and large $\mathrm{S}$ waves in III and AVF. The chest X-ray demonstrated an increased heart area. An abdominal CT scan showed bilateral pleural effusion, liver and spleen enlargement, and liquid in the pelvic cavity.

During the 11-day hospitalization period, the patient's temperature fluctuated from normal to $38^{\circ} \mathrm{C}$. Hydration and electrolytes were normal. Creatinine levels initially rose to 10.4 and later to $13.1 \mathrm{mg} / \mathrm{dL}$, requiring hemodialysis. The patient received six blood transfusions in total, elevating the hemoglobin to $11.8 \mathrm{~g} / \mathrm{dL}$. The patient died of respiratory distress due to acute failure of heart and kidneys. He never did receive benznidazole because of hospital shortage. Parents did not consent to an autopsy.

T. cruzi DNA was extracted from the FTA card. Genotyping was performed by PCR-RFLP, following the methodology developed by Lewis et al. (2009) [15]. Briefly, fragments of the D7 divergent domain of the 24S $\alpha$ rRNA locus (LSU rDNA), glucose-6-phosphate isomerase (GPI) and heat shock protein 60 (HSP60) genes were amplified with specific primers; the size of amplicons and restriction fragments after digestion with restriction enzymes ( $E c o$ RV for HSP60 and Hha I for GPI) were compared to those of reference T. cruzi strains (Fig. 1). Additionally, a multiplex PCR assay targeting the mini-exon gene [16] was also performed (Fig. 2). In both cases, the T. cruzi isolate from the patient matched the pattern of DTU TcI. Written consent to publish the case was provided by the patient's wife. 


\section{Discussion and conclusions}

This is the first time in Ecuador to genotype T. cruzi TcI (DTU) from a human source, although the patient did not survive in the acute phase of the Chagas disease. To date, TcI is the predominant DTU in Ecuador, as evidenced in studies but involving reservoirs and vectors from different geographic regions $[4,11]$. It is in concordance with previous reports from the northern region of South America that showed DTU TcI being predominant in the neighboring countries of Colombia and Venezuela $[17,18]$. It has been hypothesized that TcI can escape the host's acute immune response, remain in the peripheral blood mononuclear cells and then parasitize organs faster $[5,19]$. The present case suggests that the TcI strain circulating in the country are capable of causing fatal acute disease. Hence, further research is needed to identifying the genetic lineages of $T$. cruzi DTU in different clinical presentations and the severity of the Chagas disease.

Acute Chagas cases resulting in death have been documented, mostly from oral contamination and found most frequently in the Amazon region [20]. Most of these cases were due to TcI, with rare cases due to TcIII and TcIV [2123], TcI in Venezuela and French Guiana [24, 25] and TcII in southern Brazil [26]. However, in this case, the infection apparently occurred via the vectorial route, as suggested by the presence of a chagoma, i.e. the pruritic papular lesion that evolved into an ulcer in the left leg, starting 10 days before the appearance of fever and malaise. The presence of $T$.

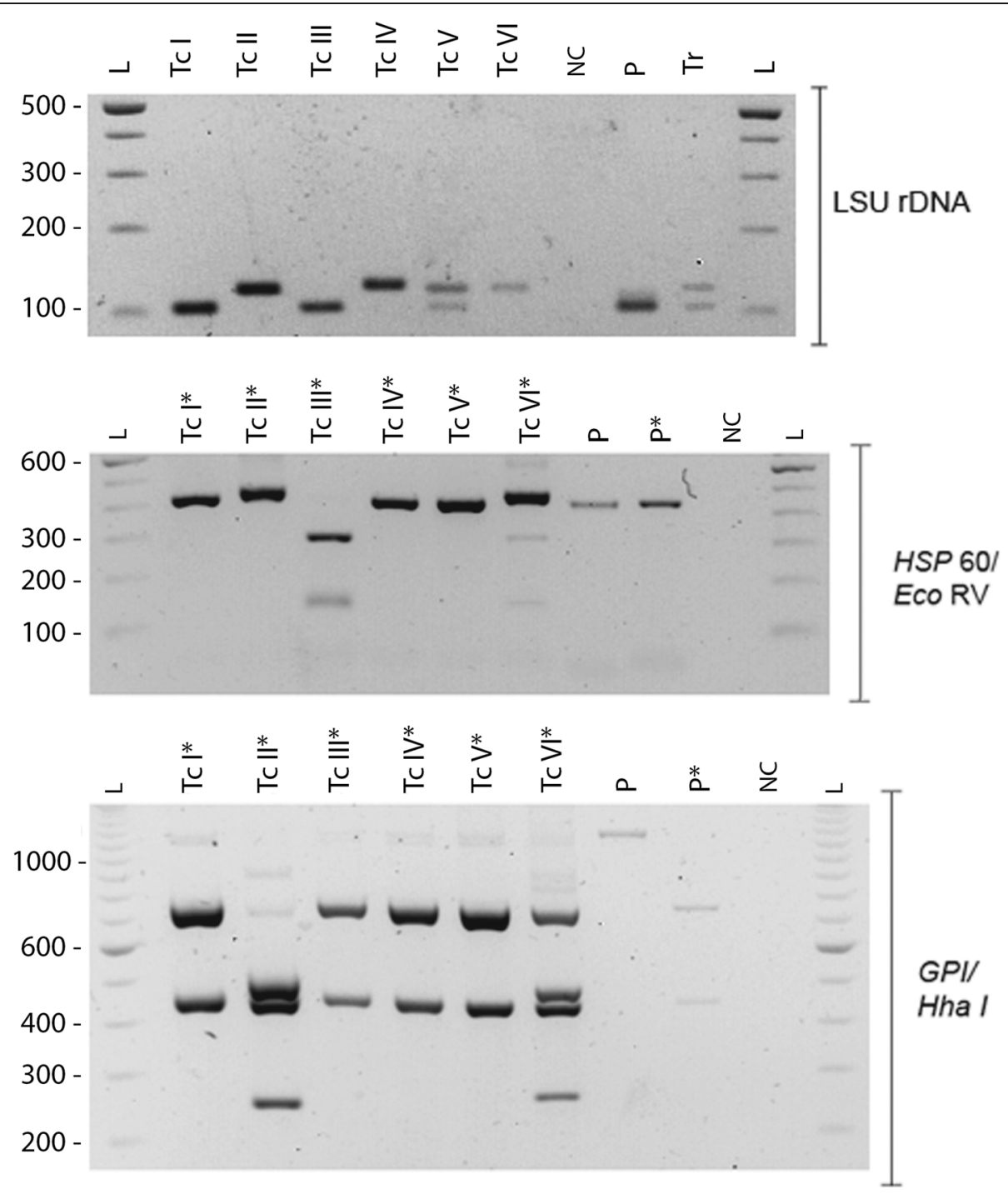

Fig. 1 T. cruzi genotyping by PCR-RFLP. As indicated by the brackets on the right side, specific fragments from the LSUr DNA, HSP60 and GPI genes were amplified by PCR. GPI and HSP60 amplification products were digested with Hhal and EcoRV restriction enzimes, respectively. L: DNA molecular weight ladder, with the corresponding molecular weights in base-pairs indicated on the left of the gels. Tcl-TcVI: DTU controls. N: Negative (no template) control. P: DNA isolated from the patient's blood. Tr: T. rangeli DNA. Lanes containing restriction products are labeled with an asterisk $\left(^{*}\right)$. Only restriction products are shown for controls 


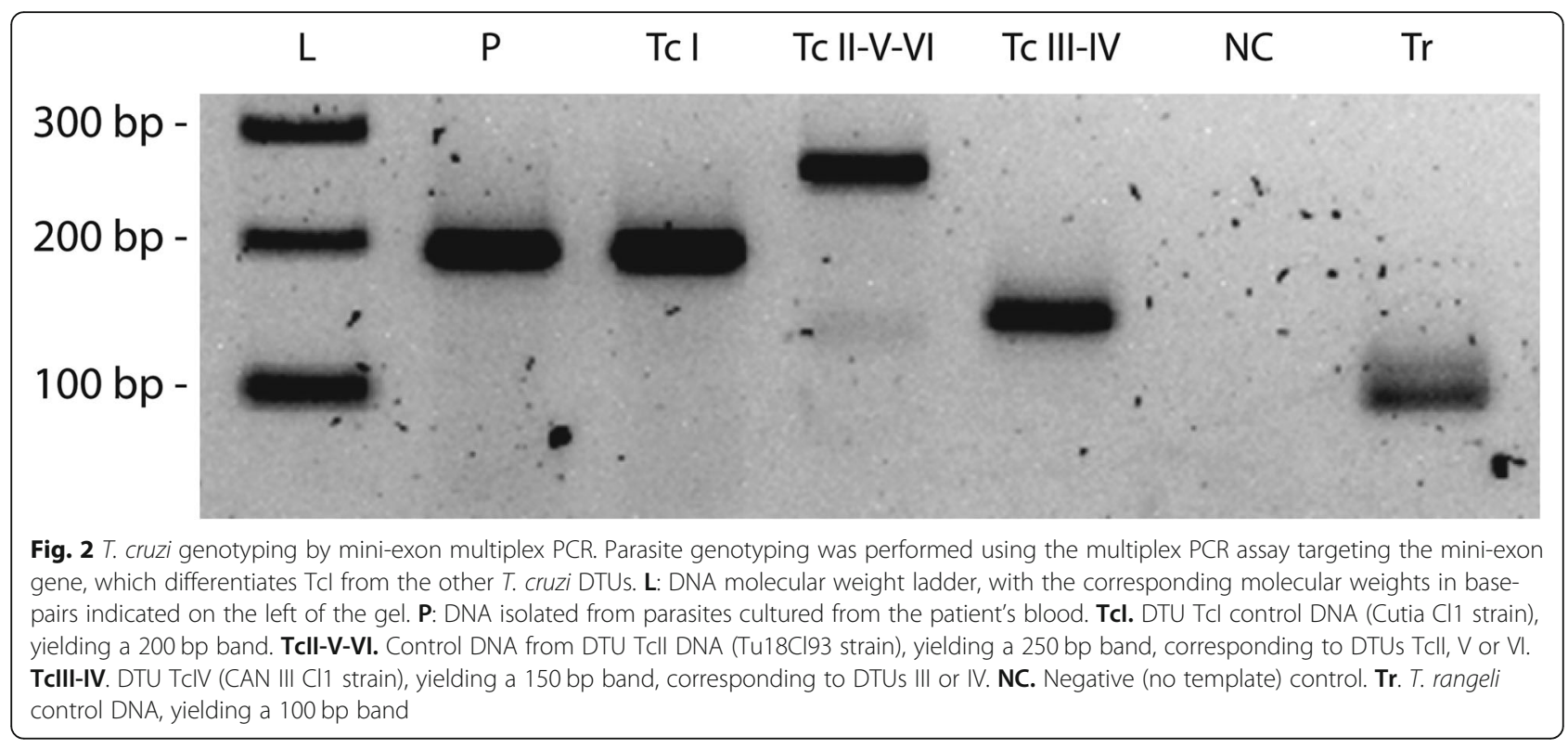

cruzi vectors has been reported in Cotopaxi province, specifically Triatoma carrioni and T. dispar [27].

Symptoms frequently reported in acute fatal cases of Chagas disease are hepatomegaly (100\%), myocarditis (75\%), pericardial effusion (50\%), cardiomegaly $(25 \%)$ or acute kidney failure (AKF) $[10,17,20]$. In the present case, the patient was clearly in the acute phase, because of the duration of the symptoms and the absence of anti-T. cruzi IgM and IgG antibodies. The absence of antibodies would be explained because 1) In order to develop detectable antibodies, it generally takes at least 3 to 4 weeks [28]. 2) In acute cases reported in Venezuela, specific IgM antibodies were demonstrated only in $87.3 \%$ of cases, and the transmission was oral, that is considered more severe, because of the rapid entry of parasites into the blood stream [24]. Hence, prompt development of antibodies can occur when compared to a natural infection caused by a triatomine bite, as probably occurred in our case. 3) Another explanation could be because of the different antigens used in the ELISA techniques performed, in-house with the delipidised antigen specific for $T$. cruzi epimastigotes [24] would detect prompt antibodies rather than we used the commercially ELISA method Chagatest ELISA recombinant, Version 3.0. Wiener-Rosario, Argentina, based on six recombinant proteins. Severe symptomatology is known to occur in immunocompromised patients [7]. However, our patient had no history of taking immunosuppressive drugs and was HIV-negative. The symptoms present in our patient including edema, EKG alterations, cardiomegaly, bilateral pleural effusion and the elevation of creatinine and blood urea nitrogen, strongly suggested acute myocarditis and AKF. The latter condition is usually marked by a rise in serum creatinine concentration or by azotemia.
High mortality in acute cases of Chagas disease has been linked to lack of prompt diagnosis and treatment. Both may have contributed to worsening of the patient's condition and his subsequent death. We strongly advise health-care providers, lab technicians, physicians, as well as decision-makers in the central health entities to increase awareness about Chagas disease, and to improve the availability and distribution of anti-T. cruzi medication in the country. This case exemplifies the challenges faced by the local healthcare system in this regard, and constitutes an urgent call for action in order to ensure early diagnosis and prompt treatment is available to all chagasic patients in Ecuador.

\section{Abbreviations}

AKF: Acute kidney failure; DTUs: Discrete typing units;

EKG: Electrocardiogram; ELISA: Enzyme-linked immunosorbent assay; HBCAg: Anti-core hepatitis; HBsAg: Hepatitis B surface antigen; HCV: Hepatitis C Virus; HIV: Human Immunodeficiency Virus; MPH: Ministry of Public Health; PAHO: Pan American Health Organization; PCR-RFLP: Polymerase Chain Reaction-Restriction fragment length polymorphism; VDRL: Venereal Disease Research Laboratory test; WHO: World Health Organization

\section{Acknowledgements}

The authors would like to thank Camila Cilveti and Jalil Maiguashca Sánchez for technical assistance, and Ronald Guderian for reviewing this manuscript.

\section{Authors' contributions}

MC: Overall coordination, writing, editing and revision of manuscript. WC, GS: Diagnosis and management of patient, writing and editing of manuscript. VV, JA, AG: Parasitological and molecular diagnosis, writing and editing of manuscript. All authors read and approved the final manuscript.

\section{Funding}

None.

Availability of data and materials

All relevant data and materials are included in the manuscript. 


\section{Ethics approval and consent to participate}

The Hospital Director and the patient's wife signed a consent to obtain the data from the clinical record, after patient death.

\section{Consent for publication}

Written informed consent for publication of clinical details was obtained from the patient's wife.

\section{Competing interests}

The authors declare that they have no competing interests.

\section{Author details}

'OneHealth Research Group, Carrera de Medicina, Facultad de Ciencias de la Salud, Universidad de Las Américas (UDLA), Calle Jose Queri $s / n$ entre Av. Granados y Av. Eloy Alfaro, PO BOX 17-17-9788, Quito, Ecuador. ${ }^{2}$ Instituto de Biomedicina, Carrera de Medicina, Facultad de Ciencias Médicas, Universidad Central del Ecuador, Quito, Ecuador. ${ }^{3}$ Centro de Investigación para la Salud en América Latina (CISeAL), Escuela de Ciencias Biológicas, Pontificia Universidad Católica del Ecuador, Quito, Ecuador.

Received: 19 September 2019 Accepted: 6 February 2020

Published online: 14 February 2020

\section{References}

1. World Health Organization. Chagas disease (American trypanosomiasis). Geneva: World Health Organization Washington; 2018. Accessed 19 June 2018: http://www.who.int/news-room/fact-sheets/detail/ chagas-disease (american-trypanosomiasis)

2. Messenger LA, Miles MA, Bern C. Between a bug and a hard place: Trypanosoma cruzi genetic diversity and the clinical outcomes of Chagas disease. Expert Rev Anti Infect Ther. 2015;13(8):995-1029. https://doi.org/10. 1586/14787210.2015.1056158

3. Zingales B. Trypanosoma cruzi genetic diversity: something new for something known about Chagas disease manifestations, serodiagnosis and drug sensitivity. Acta Trop. 2018;184:38-52.

4. Costales JA, Jara-Palacios MA, Llewellyn M, Messenger LA, Ocaña-Mayorga S, Villacís AG. Trypanosoma cruzi population dynamics in the Central Ecuadorian Coast. Acta Trop. 2015;151:88-93.

5. Diaz-Bello Z, Thomas MC, Lopez MC, Zavala-Jaspe R, Noya O, Alarcón de Noya B. Trypanosoma cruzi genotyping supports a common source of infection in a school-related oral outbreak of acute Chagas disease in Venezuela. Epidemiol Infect. 2014;142(1):156-62.

6. Nicholls RS, Cucunubá ZM, Knudson A, Flórez AC, Montilla M, Puerta CJ, Pavía PX. Enfermedad de Chagas aguda en Colombia, una entidad poco sospechada. Informe de 10 casos presentados en el período 2002 a 2005. Biomédica. 2007;27(Supl.1):8-17.

7. World Health Organization. Control of Chagas Diseases. Geneva: WHO Technical Report Series. Second report of the WHO Expert Committee; 2002. p. 1-106.

8. Hollowed J, McCullough M, Sanchez D, Traina M, Hernandez S, Murillo E. Rapidly progressing Chagas cardiomyopathy. Am J Trop Med Hyg. 2016;94:894-6.

9. Carme B, Aune I, Nguyen G, Aznar C, Beaudet B. Four Cases of Acute Chagasic Myocarditis in French Guiana. Am J Trop Med Hyg. 2001;64:162-3.

10. Pinto AYN, Valente SAS, Valente VC. Emerging Acute Chagas Disease in Amazonian Brazil: Case Reports with Serious Cardiac Involvement. Brazilian J Infect Dis. 2004;8(6):454-60.

11. Ocana-Mayorga S, Llewellyn MS, Costales JA, Miles MA, Grijalva MJ. Sex, subdivision, and domestic dispersal of Trypanosoma cruzi lineage I in southern Ecuador. PLoS Negl Trop Dis. 2010;4(12):e915 [PubMed: 21179502].

12. Garzón EA, Barnabé C, Córdova X, Bowen C, Paredes W, Gómez E, Ouaissi A, Tibayrenc M, Guevara AG. Trypanosoma cruzi isoenzyme variability in Ecuador: first observation of zymodeme III genotypes in chronic chagasic patients. Trans R Soc Trop Med Hyg. 2002;96(4):378-82.

13. Bhattacharyya T, Mills EA, Jansen AM, Miles MA. Prospects for Trypanosoma cruzi lineage-specific serological surveillance of wild mammals. Acta Trop. 2015;15:182-6.

14. Abad-Franch F, Aguilar M. Control de la Enfermedad de Chagas en el Ecuador. Quito, Diciembre 2002 - Febrero: OPS/OMS - Ministerio de Salud Pública del Ecuador; 2003.

15. Lewis MD, Ma J, Yeo M, Carrasco HJ, Llewellyn MS, Miles MA. Genotyping of Trypanosoma cruzi: systematic selection of assays allowing rapid and accurate discrimination of all known lineages. Am J Trop Med Hyg. 2009; 81(6):1041-9.

16. Fernandes $O$, Santos SS, Cupolillo E, Mendonça B, Derre R, Junqueira AC, Santos LC, Sturm NR, Naiff RD, Barret TV, Campbell DA, Coura JR. A miniexon multiplex polymerase chain reaction to distinguish the major groups of Trypanosoma cruzi and T. rangeli in the Brazilian Amazon. Trans R Soc Trop Med Hyg. 2001;95(1):97-9.

17. Añez N, Crisante G, da Silva FM, Rojas A, Carrasco H, Umezawa ES, Stolf AM, Ramirez JL, Teixeira MM. Predominance of lineage I among Trypanosoma cruzi isolates from Venezuelan patients with different clinical profiles of acute Chagas" disease. Trop Med Int Health. 2004;9(12):1319-26.

18. Mejia-Jaramillo AM, Pena VH, Triana-Chavez O. Trypanosoma cruzi: Biological characterization of lineages I and II supports the predominance of lineage I in Colombia. Exp Parasitol. 2009;121(1):83-91 [PubMed: 18950627].

19. Cassini AL, de Abreu Vieira PM, Mendes Roatt B, Oliveira Aguiar-Soares RD. The TCl and Tcll Trypanosoma cruzi experimental infections induce distinct immune responses and cardiac fibrosis in dogs. Mem Inst Oswaldo Cruz. 2014;109(8):1005-13.

20. Cavalcante dos Santos VR, de Meis J, Savino W, JA AA, dos santos Vieira JR, Coura JR, Verissimo Junqueira AC. Acute Chagas disease in the state of Pará, Amazon Region: is it increasing? Mem Inst Oswaldo Cruz. 2018;113(5):e170298.

21. Coura JR. Transmission of chagasic infection by oral route in the natural history of Chagas disease. Rev Soc Bras Med Trop. 2006;39:113-7.

22. Marcili A, Lima L, Valente VC, Valente SA, Batista JS, Junqueira AC, Souza Al, da Rosa JA, Campaner M, Lewis MD, Llewellyn MS, Miles MA, Teixeira MM. Comparative phylogeography of Trypanosoma cruzi TCIlc: new hosts, association with terrestrial ecotopes ans spatial clustering. Infect Genet Evol. 2009;9(6):1265-74.

23. Valente $S A$, da Costa $W$, das Neves Pinto AY, de Jesus Barbosa César M, dos Santos MP, Miranda CO, Cuervo P, Fernandes O. Analysis of an acute Chagas disease outbreak in the Brazilian Amazon: human cases, triatomines, reservoir mammals and parasites. Trans R Soc Trop Med. 2009;103:291-7.

24. Alarcón de Noya BA, Díaz-Bello Z, Colmenares C, Ruiz-Guevara R, Mauriello L, Muñoz-Calderón A, Noya O. Update on oral Chagas disease outbreaks in Venezuela: epidemiological, clinical and diagnostic approaches. Mem Inst Oswaldo Cruz. 2015;110(3):377-86.

25. Coura JR. Chagas disease: control, elimination and eradication. Is it possible? Mem Inst Oswaldo Cruz. 2013;108(8):962-7.

26. Steindel M, Pacheco LK, Scholl D, Soares M, de Moraes MH, Eger I, Kosmann C, Sincero TC, Stoco PH, Murta SM, de Carvalho-Pinto CJ, Grisard EC. Characterization of Trypanosoma cruzi isolated from humans, vectors and animal reservoirs following an outbreak of acute human Chagas disease in Santa Catarina state, Brazil. Diagn Microbiol Infect Dis. 2008;60:25-32.

27. Abad-Franch F, Paucar A, Carpio C, Cuba CA, Aguilar HM, Miles MA. Biogeography of Triatominae (Hemiptera: Reduviidae) in Ecuador: implications for the design of control strategies. Mem Inst Oswaldo Cruz. 2001;96(5):611-20.

28. Janeway CA, Travers $P$, Walport M, Shlomchik MJ. In: Janeway CA, Travers $P$, Walport M, Shlomchik MJ, editors. Adaptative immunity to infection. 5th ed. New York: Churchill Livingstone; 2001. p. 381-423. Immunobiology.

\section{Publisher's Note}

Springer Nature remains neutral with regard to jurisdictional claims in published maps and institutional affiliations.

Ready to submit your research? Choose BMC and benefit from:

- fast, convenient online submission

- thorough peer review by experienced researchers in your field

- rapid publication on acceptance

- support for research data, including large and complex data types

- gold Open Access which fosters wider collaboration and increased citations

- maximum visibility for your research: over $100 \mathrm{M}$ website views per year

At $\mathrm{BMC}$, research is always in progress.

Learn more biomedcentral.com/submissions 